\title{
Regulation Simplification and Implementation of Regulatory Reform Agenda
}

\author{
Mohamad Iksan Maolana ${ }^{1}$ \\ Kementerian Perencanaan Pembangunan Nasional/BAPPENAS - Republik Indonesia
}

\begin{abstract}
Nowadays, the conditions of regulation in Indonesia, from quatity perspective, are within overregulated position or in another word, number of regulation which exist is too excessive. Moreover, withn quality perspective, there are many inconsistent regulation, overlapping and contradicted each other. Those conditions has negative significant especially in its relationship with the investation climate and business competition in Indonesia. In last 2014, The President Joko Widodo has mandated the ministries to apply simplification of regulation through the pruning about 50\% from 42000 regulations which currently prevail in Indonesia. This article aims to observe the significant of regulation simplification in Indonesia by draw the success implementation of regulation simplification in South Korea. This article also discusses the steps which should be applied by the Indonesia government in order to implement the regulation simplification. In the last chapter, this article will portray the potencial obstacles that will be faced by the government during the process of implementation of regulation simplification in Indonesia and also suggest the solution to answer those prob
\end{abstract}

Keyword: Regulation, Regulatory Reform 


\section{Simplifikasi Regulasi Sebagai Langkah Awal Pelaksanaan Agenda Reformasi Regulasi di Indonesia}

\section{Mohamad Iksan Maulana, BAPPENAS}

\section{Pendahuluan}

"Kita negara hukum, bukan negara Undang-Undang atau negara peraturan." Ungkapan tersebut disampaikan oleh Presiden Jokowi pada Bulan Oktober $2016^{2}$ sebagai tanda awal mula pelaksanaan reformasi hukum besar-besaran di Indonesia. Meskipun dalam Undang Undang Dasar Negara Republik Indonesia Pasal 1 ayat ( 3$)^{3}$ dinyatakan bahwa "Indonesia adalah negara hukum" namun bukan berarti segala kegiatan yang diselenggarakan oleh lembaga negara termasuk pemerintah, harus diatur dalam sebuat peraturan perundang-undangan. Paradigma tersebut yang mulai akan disebarkan oleh Presiden kepada seluruh lembaga negara yang berwenang membentuk peraturan perundang-undangan dengan melihat pada kondisi perundang-undangan di Indonesia selama ini.

Pada periode tahun 2000-2015, pemerintah telah menerbitkan 12.471 regulasi dengan kontribusi terbanyak yaitu dari peraturan setingkat menteri yang berjumlah 8.311 regulasi. ${ }^{4}$ Jumlah tersebut belum termasuk peraturan pelaksanaan setingkat peraturan Direktur Jenderal atau yang selevel dan juga regulasi yang dikeluarkan oleh pemerintah daerah di seluruh Indonesia. Kondisi tersebut kemudian yang saat ini disebut sebagai hyper-regulation, yaitu konidisi dimana jumlah regulasi yang berlebihan justru akan menjadi beban bagi pemerintah untuk melaksanakan pembangunan karena tingginya potensi konflik dan tumpang tindih peraturan. Diperlukan sebuah solusi yang jitu, holistik, tepat sasaran dan dilakukan secara serentak oleh seluruh elemen pemerintah (whole government approach), untuk memperbaiki kondisi regulasi yang ada di Indonesia saat ini.

Pada Tahun 2015, Kementerian Perencanaan Pembangunan Nasional/Badan Perencanaan Pembangunan Nasional me-launching Buku Strategi Nasional Reformasi Regulasi (Stranas RR). Stranas RR terinspirasi oleh praktik Reformasi Regulasi terbaik di berbagai negara antara lain Korea Selatan yang mengalami kondisi krisis ekonomi sama dengan Indonesia pada tahun 1998, namun dengan cepat bangkit dari keterpurukan yang salah satu solusinya yaitu dengan memangkas 50 persen dari 11.125 (sebelas ribu seratus dua puluh lima) regulasi di bidang ekonomi. ${ }^{5}$

Stranas RR terdiri dari 4 (empat) strategi utama, namun dalam penulisan artikel kali ini difokuskan pada agenda pertama yaitu "Simplifikasi Regulasi". Agenda simplifikasi regulasi menjadi sangat penting untuk memulai langkah pelaksanaan reformasi regulasi di Indonesia. Adapun tujuan dari penulisan yaitu untuk memberikan informasi dan membuka wawasan pengetahuan kepada para pemangku kepentingan terutama di kalangan internal pemerintah yang memiliki kewenangan membentuk dan mencabut regulasi, tentang urgensi pelaksanaan simplifikasi regulasi/ pemangkasan regulasi. Langkah-langkah simplifikasi regulasi yang tepat akan menentukan keberhasilan pelaksanaan ke depan. Selain itu penelitian juga akan menganalisis hambatan dalam pelaksanaan simplifikasi regulasi dan juga solusi terhadap hambatan tersebut agar dapat tercapai tujuan agenda reformasi regulasi di masa yang akan datang.

\section{Pembahasan}

\subsection{Agenda Reformasi Regulasi di Indonesia}

Reformasi regulasi dipandang sebagai agenda strategis, baik di negara maju maupun negara berkembang seperti Indonesia, sebagai salah satu instrumen inti yang dimiliki pemerintah untuk mengelola ekonomi, mempengaruhi perilaku usaha, dan melaksanakan kebijakan sosial. Dalam iklim ekonomi global yang penuh dengan tantangan dari berlanjutnya ketidakstabilan di pasar

\footnotetext{
2. Qodar, Nafiysul, 2016, Jokowi: Kita Negara Hukum, Bukan Negara Undang-Undang, diakses melalui website: http://news.liputan6.com/ read/2623831/jokowi-kita-negara-hukum-bukan-negara-undang-undang

3. UUD NRI 1945, diakses melalui website: https://portal.mahkamahkonstitusi.go.id/eLaw/mg58ufsc89hrsg/UUD_1945_Perubahan.pdf

4. Kementerian Perencanaan Pembangunan Nasional/Bappenas, 2015. Strategi Nasional Reformasi Regulasi: Mewujudkan Regulasi yang Sederhana dan Tertib. Kementerian PPN / Bappenas, Jakarta, Indonesia, hal:5

5. Djalil, Sofyan, 2015, disampaikan dalam acara Peluncuran Strategi Nasional Reformasi Regulasi: Mewujudkan Regulasi Yang Sederhana dan Tertib, Jakarta, 6 Oktober 2015 di Gedung Bappenas.
} 
keuangan dan juga meningkatnya beban fiskal untuk menyediakan layanan umum penting seperti kesehatan, pendidikan dan jaminan sosial, negara modern harus memanfaatkan kekuasaannya melalui regulasi yang semakin cerdas dan berkualitas. Dalam konteks Indonesia, reformasi regulasi juga merupakan salah satu ambisi usaha negara untuk mengonsolidasikan proses penyusunan peraturan perundang-undangan yang demokratis, meningkatkan pertumbuhan ekonomi menjadi lebih pesat untuk dapat bersaing dengan ekonomi besar lain di wilayahnya dan mewujudkan tujuan-tujuan kesejahteraan bagi masyarakat Indonesia. ${ }^{6}$

Secara umum, definisi Reformasi Regulasi adalah perubahan-perubahan yang dimaksudkan untuk meningkatkan kualitas regulasi, baik secara individual maupun integral (ter-integrasi dalam suatu sistem regulasi yang komprehensif dan utuh). Reformasi Regulasi memiliki tujuan jangka pendek yaitu untuk meningkatkan kualitas regulasi dan tujuan jangka panjang untuk mewujudkan Sistem Regulasi Nasional (SRN). Namun, substansi reformasi regulasi dapat berbeda antara negara yang satu dengan negara lainnya, tergantung pada kompleksitas permasalahan yang dihadapi. ${ }^{7}$

Sejak tahun 2010, Bappenas sudah memulai untuk merintis pelaksanaan reformasi regulasi di Indonesia berdasarkan pada kondisi faktual regulasi yang ada di Indonesia saat ini antara lain sebagai berikut: ${ }^{8}$

- Terlalu banyak regulasi (hyper-regulation) : kondisi dimana jumlah regulasi yang ada sangat berlebihan dan pada akhirnya justru akan menjadi beban karena pada akhirnya menimbulkan ketidakpastian hukum sehingga berdampak pada daya saing dan iklim investasi di Indonesia.

- $\quad$ Saling bertentangan (conflicting): Banyak materi muatan regulasi yang bertentangan, baik yang sifatnya vertikal, maupun horizontal yang berakibat pada ketidakpastian dalam pelaksanaannya.

- Tumpang Tindih (overlapping): Banyak peraturan perundang-undangan yang mengatur tentang hal yang sama bahkan dalam satu Kementerian/Lembaga (K/L). Hal ini seharusnya sudah dapat teridentifikasi sejak awal pengusulan pembentukan suatu regulasi agar tidak terjadi pemborosan anggaran.

- Multitafsir (multi Interpretation): Banyak ketentuan regulasi yang mengandung materi muatan yang bersifat multi tafsir sehingga berakibat pada ketidakpastian dan perbedaan dalam implementasinya, selain juga rentan akan kemungkinan disalahgunakan untuk kepentingan tertentu.

- Tidak Taat Asas (inconsistency): Ketidaktaatan terhadap asas di Indonesia terkait dengan hubungan antara kebijakan dengan regulasi. Di banyak regulasi, ditemukan bahwa regulasi tidak konsisten dengan kebijakan yang mendasarinya. Hal ini akan membingungkan berbagai stakeholder yang mendasari segala aktifitasnya pada regulasi tersebut.

- Tidak Efektif: Banyak regulasi yang tidak efektif pada saat pengimplementasiannya dikarenakan beberapa hal sepeti tidak memadainya persiapan dalam implementasi suatu peraturan perundang-undangan baik dari aspek sosialisasi, penyiapan struktur organisasi pelaksana, kesiapan sumber daya manusia dari sisi kompetensi, maupun dukungan pengadaan.

- Menciptakan beban yang tidak perlu(unnecessary Burden):Bebanyang tidak perlu dari dibentuknya sebuah regulasi terkadang muncul pada saat pengimplementasiannya, baik itu terhadap kelompok sasaran (targeted group) maupun non-kelompok sasaran (non-targeted group).

- Menciptakan ekonomi biaya tinggi (High-Cost Economy): jumlah regulasi yang kurang proporsional (bahkan berlebihan), telah menciptakan ekonomi biaya tinggi. Hal tersebut jelas akan menambah biaya produksi, sehingga produk atau jasa yang dihasilkan akan menjadi kurang kompetitif dengan barang dan jasa yang dihasilkan oleh negara lain.

Berdasarkan kondisi regulasi yang ada di Indonesia tersebut, beberapa K/L berinisiatif

\footnotetext{
6. the Organisation for Economic Co-operation and Development (OECD), 2012, Kajian OECD mengenai Reformasi Regulasi Indonesia: Memperkuat Koordinasi dan Menguatkan Pasar, September 2012, Jakarta, Indonesia

7. Strategi Nasional Reformasi Regulasi: Mewujudkan Regulasi yang Sederhana dan Tertib, Loc Cit, hal: 13-14

8. Direktorat Analisa Peraturan Perundang-undangan-Bappenas, Pemetaan Hasil Identifikasi terhadap Undang-Undang Sektor yang Berpotensi Bermasalah, disampaikan pada Workshop Koordinasi Strategi Analisa Peraturan Perundang-undangan, Jakarta, 5 Desember 2012. Pemetaan dilakukan oleh 10 direktorat di lingkungan Bappenas serta Undang-Undang yang dilakukan secara Self-Assessment.
} 
untuk melakukan reformasi regulasi yang dimulai dari $\mathrm{K} / \mathrm{L}$ masing-masing dengan melihat urgensi pelaksanaan reformasi regulasi bagi agenda $\mathrm{K} / \mathrm{L}$ tersebut. Beberapa $\mathrm{K} / \mathrm{L}$ yang telah melaksanakan agenda reformasi regulasi diantaranya Kantor Kemenko Perekonomian, Bappenas, Kementerian Hukum dan HAM (BPHN), Kementerian Tenaga Kerja dan Transmigrasi, Kementerian Perindustrian, Kementerian Pendidikan dan Kebudayaan, Badan Standardisasi Nasional, Lembaga Sandi Negara, dan lain-lain. ${ }^{9}$

Di Bappenas sendiri setidaknya sudah ada 2 (dua) inisiasi agenda terkait reformasi regulasi yaitu: 1) Pengintegrasian Kerangka Regulasi dalam Dokumen Perencanaan Pembangunan Nasional, sebagaimana tercermin dalam Rencana Pembangunan Jangka Menengah Nasional (RPJMN) 2015-2019; dan 2) Penerbitan Buku Strategi Nasional Reformasi Regulasi 20152025..$^{10}$

Pada Strategi Nasional Reformasi Regulasi di Indonesia, memuat 2 (dua) dimensi strategi yaitu untuk regulasi yang sudah ada (existing regulation) dan regulasi yang akan dibentuk (future regulation). Pada masing-masing dimensi tersebut, terdapat strategi-strategi yang dapat dilihat pada Gambar 1 berikut : ${ }^{11}$

Gambar 1. Strategi Nasional Reformasi Regulasi di Indonesia
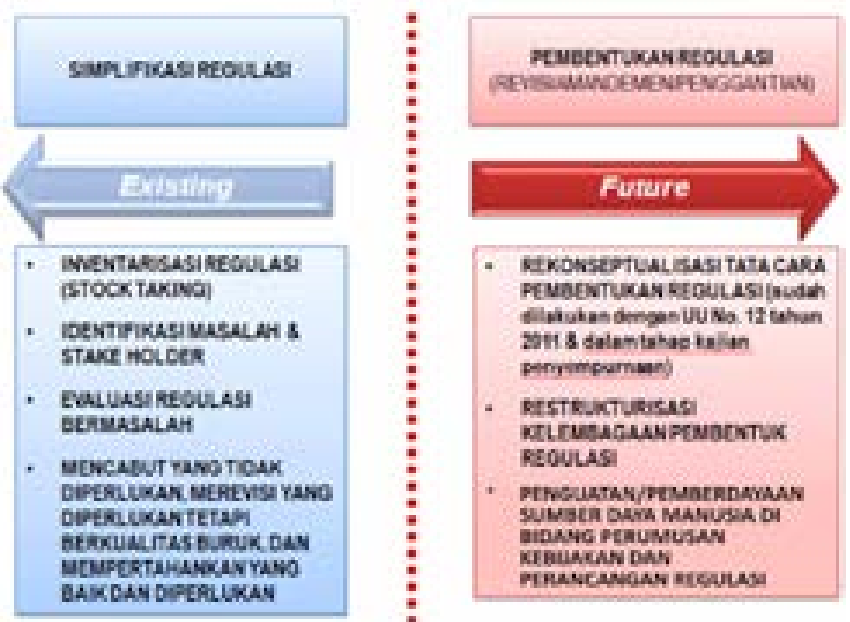

Pada Gambar 1 di atas, "Simplifikasi Regulasi" merupakan strategi yang akan dilaksanakan oleh pemerintah untuk mengatasi permasalahan regulasi yang telah dibentuk (existing regulation). Ada 4 (empat) langkah besar untuk melaksanakan simplifikasi regulasi di Indonesia yaitu: 1) inventarisasi regulasi (stock tacking) yang dapat dilakukan oleh masing-masing K/L berdasarkan kewenanangannya; 2) Identifikasi Permasalahan dan stakeholder terkait; 3) Evaluasi regulasi bermasalah; 4) Dari hasil 3 kegiatan di atas, akan diambil keputusan untuk: mencabut regulasi yang tidak diperlukan, merevisi regulasi yang masih dibutuhkan namun perlu perbaikan kualitas, dan mempertahankan regulasi yang masih baik dan diperlukan. Penjelasan lebih lanjut terkait simplifikasi regulasi akan dibahas pada sub-bab selanjutnya.

\subsection{Simplifikasi Regulasi Sebagai Langkah Awal Pelaksanaan Agenda Reformasi Regulasi di Indonesia}

The Organisation for Economic Co-operation and Development (OECD) menyatakan bahwa agenda reformasi regulasi, termasuk di dalamnya program simplifikasi administrasi (simplifikasi regulasi) adalah dengan menciptakan kerangka kerja untuk mempromosikan peningkatan kualitas regulasi, dalam konteks yang lebih luas termasuk juga peningkatan tata kelola transparansi, akuntabilitas, dan efisiensi pemerintahan. ${ }^{12}$

Bappenas mendefinisikan simplifikasi regulasi atau penyederhanaan regulasi sebagai cara

\footnotetext{
9. Prof. Dr. Ida Bagus Rahmadi Supancana, 2017, Sebuah Gagasan tentang Grand Design Reformasi Regulasi Indonesia, Penerbit Universitas Katolik Indonesia Atma Jaya, Jakarta, Indonesia, hal: 8-9.

10. Baca: Kementerian Perencanaan Pembangunan Nasional/Bappenas, 2015, Strategi Nasional Reformasi Regulasi: Mewujudkan Regulasi yang Sederhana dan Tertib. Kementerian PPN / Bappenas, Jakarta.

11. Strategi Nasional Reformasi Regulasi: Mewujudkan Regulasi yang Sederhana dan Tertib, Loc Cit, hal: 32

12. OECD, 2004, Implementing Administrative Simplification in OECD Countries: Experiences and Challenges, terjemahan, hal: 2, diakses melalui website http://www.oecd.org/mena/governance/37026688.pdf pada tanggal 10 Februari 2017.
} 
untuk mengendalikan kuantitas terhadap regulasi yang sedang menjadi hukum positif (sedang berlaku) dalam rangka mewujudkan regulasi yang proporsional. Jumlah regulasi yang banyak mendorong pelaksanaan simplifikasi regulasi harus bersifat massal dan cepat. Oleh karena itu, kriteria yang digunakan dalam melakukan pengkajian ulang atau anlisis regulasi tersebut harus bersifat sederhana sehingga mudah diimplementasikan pada setiap K/L. ${ }^{13}$

Adapun tujuan dari simplifikasi regulasi adalah untuk mewujudkan regulasi dengan jumlah yang proporsional dan rasional dengan tetap menjaga kualitas. Melalui simplifikasi regulasi diharapkan beban regulasi menjadi berkurang, sehingga kondisi tersebut akan mendukung iklim usaha dan investasi di Indonesia. ${ }^{14}$

Presiden Joko Widodo dalam Rapat Terbatas di Istana Bogor pada 18 Desember 2015 telah menginstruksikan pemangkasan regulasi secara bertahap baik di pusat maupun di daerah yang saat ini jumlahnya mencapai sekitar 42 ribu regulasi. Presiden mengharapkan setengah dari jumlah regulasi tersebut dipangkas atau sekitar 21 ribu regulasi. Penghapusan regulasi menjadi kebutuhan mendesak agar investasi untuk pembangunan dapat berjalan dengan baik dan tanpa hambatan ke depannya. ${ }^{15} \mathrm{Hal}$ inilah yang menjadi tonggak awal pelaksanaan simplifikasi regulasi di Indonesia. Dengan adanya dukungan politik tersebut yang langsung diperintahkan oleh kepala negara, diharapkan pelaksanaan agenda reformasi regulasi di Indonesia, khususnya agenda simplifikasi regulasi, akan berjalan dengan baik dan tujuan dari reformasi regulasi dapat terwujud pada akhir pelaksanaan Strategi Nasional Reformasi Regulasi di Indonesia.

\subsubsection{Urgensi Pelaksanaan Simplifikasi Regulasi di Indonesia}

Berdasarkan data dari Worldwide Governance Indicators (WGI) pada tahun $2015^{16}$ menunjukkan kualitas regulasi di Indonesia yang masih rendah dari segi dukungan untuk kemudahan berusaha EoDB (ease of doing business). Pada regional Asia Tenggara, kualitas regulasi Indonesia berada pada angka 46\% di bawah Singapura (100\%), Brunei Darussalam (77\%), Thailand (63\%), Malaysia (75\%), dan Filipina (53\%). Posisi Indonesia hanya lebih baik dibandingkan Kamboja (35\%), Vietnam (34\%), Laos (24\%), Timor Leste (16\%), dan Myanmar (7\%). Bagi para pelaku ekonomi, rendahnya kualitas regulasi tidak hanya menjadi beban, tetapi juga menjadi kendala baik pada saat memulai maupun pada saat menjalankan usahanya di Indonesia, sehingga berdampak pada rendahnya daya saing Indonesia dalam mengarungi dinamika ekonomi internasional. Untuk lebih jelas posisi Indonesia tersebut, dapat dilihat pada Grafik 1 berikut.

Grafik 1. Persentase Kualitas Regulasi Dibandingkan Negara di ASEAN

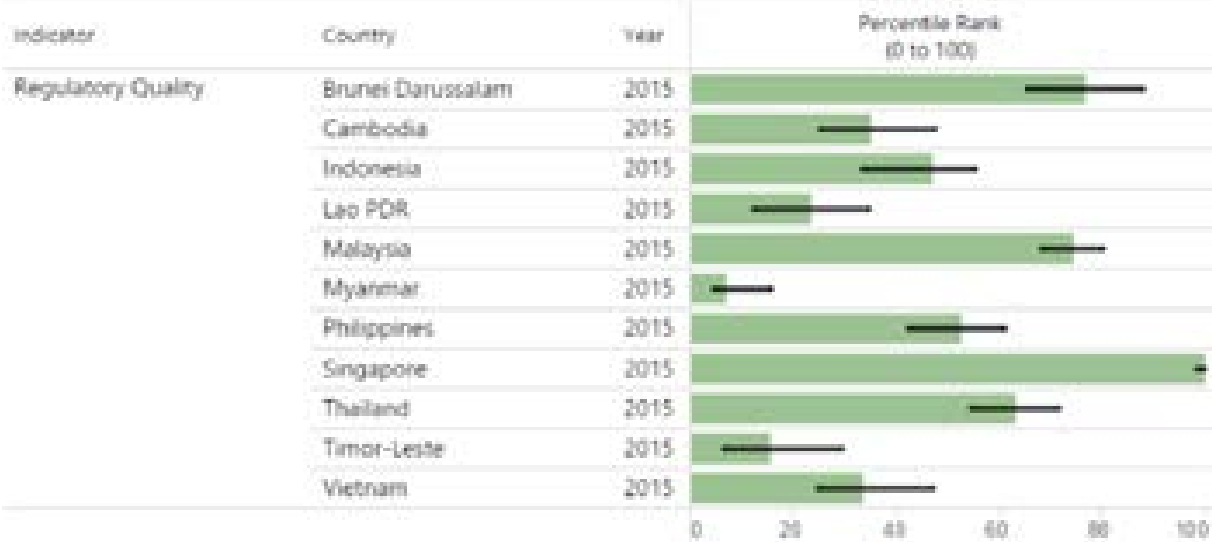

Sumber: Worldwide Governance Indicators (WGI) Regulatory Quality, 2015

\footnotetext{
13. Strategi Nasional Reformasi Regulasi: Mewujudkan Regulasi yang Sederhana dan Tertib, Loc Cit, hal: 37

14. Sebuah Gagasan tentang Grand Design Reformasi Regulasi Indonesia, Loc Cit, hal: 82.

15. Rahadian, Lalu, 2015, Pemerintah Siap Pangkas Beleid Penghambat Pembangunan, Jakarta. Diakses melalui website http://www.cnnindonesia. com/nasional/20151216121935-20-98578/pemerintah-siap-pangkas-beleid-penghambat-pembangunan/pada tanggal 30 Januari 2017.

16. Sumber: http://info.worldbank.org/governance/wgi/index.aspx\#reports Note: The Worldwide Governance Indicators (WGI) are a research dataset summarizing the views on the quality of governance provided by a large number of enterprise, citizen and expert survey respondents in industrial and developing countries. These data are gathered from a number of survey institutes, think tanks, non-governmental organizations, international organizations, and private sector firms. The WGI do not reflect the official views of the World Bank, its Executive Directors, or the countries they represent. The WGI are not used by the World Bank Group to allocate resource. Data diakses pada 10 Februari 2017
} 
Berdasarkan Grafik 1 di atas, dapat disimpulkan bahwa kualitas regulasi Indonesia masih berada pada poin yang rendah atau kurang berkualitas. Kondisi regulasi yang kurang berkualitas tersebut masih diperparah dengan jumlah regulasi yang berlebihan sehingga berdampak negatif pada iklim investasi di Indonesia. Selain itu, berdasarkan Global Competitiveness Report (GCR) 2016-2017, nilai dan peringkat Indonesia untuk indikator Burden of Government juga masih sangat rendah yaitu dengan nilai atau skor 3.9 dan berada di peringkat ke-37 dari 138 negara. ${ }^{17}$ Meskipun Indonesia mengalami perbaikan peringkat dari laporan tahun 2015-2016 18 dari peringkat ke-41 menjadi peringkat ke-37 dan juga perbaikan skor dari skor 3.8 menjadi 3.9 dari skala 1 sampai 7, posisi Indonesia dibandingkan dengan beberapa negara di Asia Tenggara saat ini masih tidak lebih baik seperti dibandingkan dengan Singapura (peringkat 1) dengan skor 5.6, Malaysia (peringkat 6) dengan skor 4.9, bahkan Laos (peringkat 35) dengan skor 3.9. Untuk memperjelas kondisi sebagaimana dimaksud, dapat dilihat pada Tabel 1 berikut.

Tabel 1. Global Competitiveness Report (GCR) 2016-2017

(Burden of Government Regulation)

\begin{tabular}{|l|c|c|}
\hline \multicolumn{1}{|c|}{ Negara } & Nilai & Ranking/138 \\
\hline Brunei Darussalam & 3.3 & 83 \\
\hline Kamboja & 3.5 & 65 \\
\hline Indonesia & 3.9 & 37 \\
\hline Laos & 3.9 & 35 \\
\hline Malaysia & 4.9 & 6 \\
\hline Myanmar & - & - \\
\hline Filipina & 2.7 & 117 \\
\hline Singapura & 5.6 & 1 \\
\hline Thailand & 3.5 & 61 \\
\hline Timor Leste & - & - \\
\hline Victnam & 3.2 & 88 \\
\hline
\end{tabular}

Sumber: Global Competitiveness Report (GCR) 2016-2017, Data Diolah Penulis

Berdasarkan pada dua data di atas, Indonesia harus segera melaksanakan reformasi regulasi karena semakin lama Indonesia mengambil tindakan, maka akan semakin memperburuk kondisi investasi di Indonesia. Simplifikasi/ pemangkasan regulasi diperlukan sebagai langkah awal pelaksanaan agenda reformasi regulasi agar upaya memperbaiki kualitas regulasi ke depan semakin lebih mudah. Indonesia dapat mencontoh pelaksanaan simplifikasi regulasi dari praktik negara-negara yang telah sukses menjalankan agenda tersebut seperti pada negara-negara OECD. Salah satu negara yang sukses menyelenggarakan agenda simplifikasi regulasi dalam hal ini yaitu Korea Selatan.

Pada tahun 1997, Korea Selatan dihantam dengan krisis finansial yang juga melanda negara-negara di Asia. Empat reformasi sektor utama diajukan untuk mengatasi krisis pada saat itu diantaranya: reformasi sektor finansial, reformasi pasar tenaga kerja, reformasi sektor korporasi, dan reformasi sektor publik. Proyeksi reformasi ke empat sektor tersebut yaitu dalam bentuk pelaksanaan reformasi regulasi dalam arti luas. Berdasarkan hasil identifikasi, terdapat 11.125 regulasi pada Januari 1998, untuk kemudian Presiden Korea Selatan pada waktu itu, Kim Dae-Jung, memerintahkan untuk mengeliminasi 50\% dari jumlah regulasi yang ada dalam jangka waktu 1 tahun atau yang dikenal dengan istilah "Guillotine Approach". Pada

\footnotetext{
17. Schwab, Klaus, 2016, World Economic Forum, Insight Report, The Global Competitiveness Report 2016-2017, dapat diakses melalui website: http://www3.weforum.org/docs/GCR2016-2017/05FullReport/TheGlobalCompetitivenessReport2016-2017_FINAL.pdf

Catatan penilaian: Bagi negara, dampak regulasi yang ada membebani bisnis/dunia usaha untuk memenuhi persyaratan Administrasi pemerintah (misalnya: izin, peraturan/regulasi, pelaporan). [Skor 1 = sangat memberatkan ; 7 = tidak memberatkan sama sekali].

18. Schwab, Klaus, 2015, World Economic Forum, Insight Report, The Global Competitiveness Report 2015-2016, dapat diakses melalui website: http://www3.weforum.org/docs/gcr/2015-2016/Global Competitiveness Report 2015-2016.pdf
} 
akhir tahun 1999, jumlah regulasi di Korea Selatan berkurang menjadi 6308, dan 2411 regulasi direvisi. Hasil tersebut berdampak positif pada semua aspek kehidupan yang dapat dilihat pada Tabel 2 berikut. ${ }^{19}$

Tabel 2. Efek Ekonomi Reformasi Regulasi Melalui Simplifikasi Regulasi di Korea Selatan

\begin{tabular}{|c|c|}
\hline \multicolumn{2}{|c|}{$\begin{array}{l}\text { EFEK EKONOMI DARI REFORMASI RECULASI MELALUI } \\
\text { SIMPUFIKASI RECULASIDI KOREA STLATAN }\end{array}$} \\
\hline Efek Ekonomi & Nilai \\
\hline Terbukaerya Lapangan Pekeria & 1066.200 lapangan pekerjaan baru \\
\hline $\begin{array}{l}\text { Berkurangnya beban masyarakat (Biaya } \\
\text { Tambahan) }\end{array}$ & $\begin{array}{l}18.7 \text { trillion won } \\
(4.4 \% \text { dari Produk Domestik Bruto pada } \\
\text { Tahun } 1997)\end{array}$ \\
\hline $\begin{array}{l}\text { Efisiensi Anckaran Negara dalam hal } \\
\text { penerapandan penegakan regulasi }\end{array}$ & 590 Ballion Won \\
\hline Meningkatnya Penanaman Modal Asing & $\begin{array}{l}\$ 36.5 \text { billion tambahan PMA dalam kurun } \\
\text { waktu } 5 \text { tahun }\end{array}$ \\
\hline $\begin{array}{l}\text { Pertumbuhan Produk Domestik Bruto } \\
\text { dalam kurun waktu } 10 \text { tahun }\end{array}$ & $8.57 \%(0.64 \%$ secara bertahap) \\
\hline Tingkat Harga Konsumen & $-7.18 \%$ \\
\hline Tingkat Pertumbuhan Tenaga Kerja & $0.94 \%$ \\
\hline Jumlah Angka Penzangguran & $-0.91 \%$ \\
\hline
\end{tabular}

Keterangan: Semua angka bersifat proyeksi

Sumber: Byung Ki Ha (1999), The Economic Effects of Korea's Regulatory Reform (in Korean), KIET. Data Diolah Penulis

Tabel di atas menunjukan efek ekonomi yang bersifat positif dari pelaksanaan simplifikasi regulasi (Guillotine Approach) di Korea Selatan. Meskipun angka-angka yang tertera pada tabel masih bersifat proyeksi pada tahun tersebut, namun setidaknya tampak terlihat bahwa ketika sebuah negara melaksanakan reformasi regulasi dengan salah satu langkahnya yaitu simplifikasi regulasi, serta didukung dengan dukungan politik dari kepala negara, maka dampak ekonomi positif akan dirasakan oleh negara tersebut. Dalam hal ini, Indonesia dapat mencontoh langkahlangkah Korea Selatan untuk memperbaiki kualitas regulasi di Indonesia. Adapun langkahlangkah tersebut akan dijelaskan pada sub-bab berikutnya.

\subsubsection{Langkah-langkah Pelaksanaan Simplifikasi Regulasi di Indonesia}

Agenda Reformasi Regulasi bersifat sangat fundamental dan holistik. Berdasarkan benchmarking study terhadap negara-negara yang telah berhasil melakukan Reformasi Regulasi, menunjukan adanya peran dan korelasi antara kemauan politik yang kuat disertai dengan kepemimpinan yang baik dari seorang kepala negara, terhadap keberhasilan Reformasi Regulasi.

Arahan Presiden Jokowi untuk memangkas 50\% dari jumlah regulasi yang ada saat ini sudah merupakan langkah awal yang sangat positif untuk memulai pekasanaan simplifikasi regulasi. Hal ini sejalan dengan langkah simplifikasi regulasi di Korea Selatan dan juga negaranegara lain yang dikenal dengan istilah Gullotine Approach, yaitu proses pemotongan regulasi. Selain itu, meskipun pelaksanaan reformasi regulasi di Indonesia belum didasarkan pada penggunaan metode analisis maupun tools yang accountable dan berstandar internasional, namun telah menunjukkan keberhasilan dan kemajuan yang sangat signifikan. Berdasarkan data, peringkat Ease of Doing Businessis di Indonesia sejak tahun 2015 terus meningkat. Pada tahun 2015, Indonesia menduduki ranking 120, kemudian menjadi ranking 109 pada tahun 2016, dan kembali naik menjadi ranking ke-91 pada tahun $2017 .{ }^{20}$ Adapun target capaian yang

19. Byung Ki Ha (1999), The Economic Effects of Korea's Regulatory Reform (in Korean), KIET, dikutip dan diterjemahkan dari http:// regulatoryreform.com/wp-content/uploads/2014/11/removeadminbarriers.pdf pada tanggal 14 Pebuari 2017.

20. Sebuah Gagasan tentang Grand Design Reformasi Regulasi Indonesia, Loc Cit, hal: 12 
disampaikan oleh Presiden Jokowi yaitu Indonesia menduduki peringkat $40^{21}$ dalam hal Ease of Doing Business, sehingga agenda reformasi regulasi harus terus diselenggarakan melalui langkah-langkah yang lebih disempurnakan, terutama pada langkah simplifikasi regulasi.

Berdasarkan pengalaman beberapa negara dan lembaga internasional dalam melaksanakan simplifikasi regulasi, setidaknya ada beberapa langkah yang penting untuk dilaksanakan, yaitu sebagai berikut :22

a. Mengidentifikasi Target dan simplifikasi;

b. Menetapkan Prioritas;

c. Mempertimbangkan Opsi-opsi;

d. Mengembangkan Kebijakan;

e. Konsultasi dan Review;

f. Persyaratan PersetujuanMengkomunikasikan Perubahan Regulasi;

g. Mengimplementasikan Proyek Pemantauan Simplifikasi; dan

h. Mendokumentasikan Manfaat yang Diraih.

Dalam praktiknya, Indonesia juga mengadopsi beberapa langkah penting di dalam pelaksanaan simplifikasi regulasi tersebut. Di dalam Strategi Nasional Reformasi Regulasi Jangka Panjang 2015-2025 dan Strategi Nasional Reformasi Regulasi Jangka Menengah 2015-2019, beberapa langkah penting tersebut terangkum dalam Instrumen Simplifikasi Regulasi (ISR). ${ }^{23}$ ISR adalah sebuah alat (tools) untuk melakukan reviu/evaluasi regulasi yang bermasalah dengan hasil akhir berupa rencana tindak. Operasionalisasi ISR dilakukan melalui proses inventarisasi regulasi, identifikasi dan klasifikasi regulasi yang bermasalah dan dilanjutkan dengan analisis regulasi. Hasil dari analisis regulasi tersebut akan memberikan tiga opsi keputusan tindakan, yaitu: (1) regulasi dipertahankan; (2) regulasi direvisi; dan (3) regulasi dicabut. Dari tiga opsi keputusan tersebut akan disusun sebuah rencana tindak yang akan dilaksanakan oleh $\mathrm{K} / \mathrm{L}$ terkait. Langkah ISR tersebut dapat dilihat pada Gambar 2 berikut.

Gambar 2. Alur Pelaksanaan Instrumen Simplifikasi Regulasi

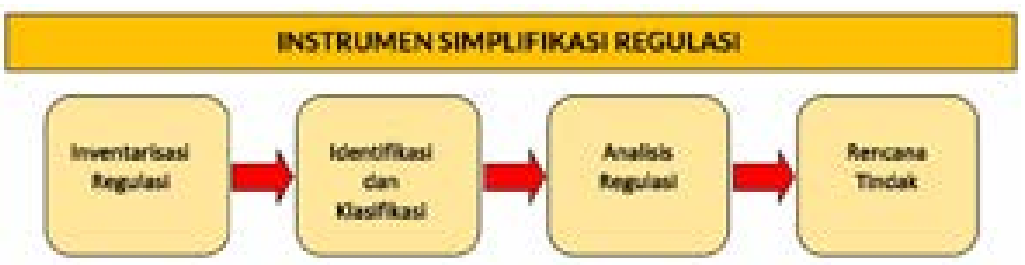

Pada tahun 2016, berdasarkan arahan Presiden Jokowi untuk melaksanakan simplifikasi regulasi, Bappenas mulai menyusun strategi untuk menentukan langkah-langkah yang lebih detail berdasarkan acuan ISR dengan ikut menggandeng K/L lain yang terkait. Dalam rangka menindaklanjuti direktif Presiden tersebut, Menteri PPN/Kepala Bappenas telah mengirimkan surat kepada seluruh Kementerian/Lembaga dan Pemerintah Daerah untuk segera melaksanakan simplifikasi regulasi di bidang perizinan dan investasi dengan target di level pusat yaitu pada 20 (dua puluh) Kementerian/Lembaga, merujuk pada Instruksi Presiden Nomor 4 Tahun 2015 Tentang Pelak-sanaan Pelayanan Terpadu Satu Pintu (PTSP) Pusat di badan Koordinasi Penanaman Modal (BKPM). ${ }^{24}$

Target yang ingin dicapai dalam rangka pelaksanaan simplifikasi regulasi tahun 2016 adalah sebagai berikut: ${ }^{25}$

A. Aksi 1: Simplifikasi $50 \%$ regulasi pada lingkup kewenangan masing-masing

\footnotetext{
21. Presiden Joko Widodo menyampaikan target tersebut pada pertemuan dengan CEO Belanda pada tanggal 23 Nopember 2016. Untuk selengkapnya, baca: HA Zen Umar Purba, Peringkat ke 40 dan Pelaksanaan Kontrak, Kompas edisi 30 Desember 2016.

22. Sebuah Gagasan tentang Grand Design Reformasi Regulasi Indonesia, Op Cit, hal: 82-83.

23. Kementerian Perencanaan Pembangunan Nasional/Bappenas, 2011, Buku Konsep Pedoman Reformasi Regulasi, Direktorat Analisa Peraturan Perundang-undangan, Kedeputian Bidang Politik, Hukum, Pertahanan dan Keamanan - Bappenas, Juni 2011, hal: 5

24. Instruksi Presiden Nomor 4 Tahun 2015 tentang Penyelenggaraan Pelayanan Terpadu Satu Pintu Pusat di Badan Koordinasi Penanaman Modal, dapat diakses melalui website http://www.kemendagri.go.id/media/documents/2015/04/22/i/n/inpres_nomor 4 tahun_2015.pdf

$20 \mathrm{~K} / \mathrm{L}$ pelaksana simplifikasi regulasi pada tahun 2016 yaitu: BKPM; Badan POM; BSN; Kementerian Agraria dan Tata Ruang; Kementerian BUMN, Kementerian ESDM; Kementerian Hukum dan HAM; Kementerian Kelautan dan Perikanan; Kementerian Kesehatan; Kementerian Tenaga Kerja; Kementerian Keuangan; Kemenkominfo; Kementerian LH dan Kehutanan; Kementerian Pariwisata; Kementerian PU dan Perumahan Rakyat; Kemendikbud; Kemendag; Kemenhub; Kementerian Perindustrian; dan Kementerian Pertanian.

25. Kementerian PPN/Bappenas, Sekretariat Stranas Reformasi Regulasi, 2017, Laporan Pelaksanaan Simplifikasi/Pemangkasan Regulasi Tahun 2016, Kementerian PPN/Bappenas, Jakarta, hal:4.
} 
Kementerian/Lembaga yang berkaitan dengan perizinan dan investasi. Aksi ini memuat target, yaitu:

1) Inventarisasi seluruh regulasi pada lingkup kewenangan masing-masing Kementerian/Lembaga;

2) Hasil identifikasi regulasi di internal Kementerian/Lembaga yang terkait perizinan dan investasi; dan

3) Hasil analisis regulasi terkait perizinan dan investasi.

B. Aksi 2: Perbaikan regulasi bermasalah pada lingkup regulasi yang menjadi kewenangan Kementerian/Lembaga lain. Aksi ini memuat target, yaitu:

1) Inventarisasi regulasi bermasalah yang menghambat Kementerian/ Lembaga pada lingkup regulasi yang menjadi kewenangan Ke-menterian/Lembaga lain;

2) Hasil identifikasi regulasi yang menghambat perizinan dan investasi dari Kementerian/Lembaga lain; dan

3) Hasil analisis regulasi.

Dalam pelaksanaan simplifikasi regulasi tersebut, Bappenas juga berkoordinasi dengan $\mathrm{K} / \mathrm{L}$ lain yang terkait seperti dengan Kementerian Koordinator Bidang Perekonomian, Kementerian Dalam Negeri, Kementerian Hukum dan HAM (terutama dengan BPHN dan Dirjen Peraturan Perundang-undangan), dan Kantor Staf Presiden. Selain dengan K/L, pelaksanaan simplifikasi regulasi juga berupaya untuk mengikutsertakan pemangku kepentingan lain yang terkait seperti dengan para pakar atau akademisi, dan pelaku usaha agar capaian simplifikasi lebih tepat sasaran. Adapun Business Process (alur pelaksanaan) Simplifikasi Regulasi secara keseluruhan pada tahun 2016 dapat dilihat pada Gambar 3 berikut: ${ }^{26}$

Gambar 3. Business Process Pelaksanaan Simplifikasi Regulasi Tahun 2016

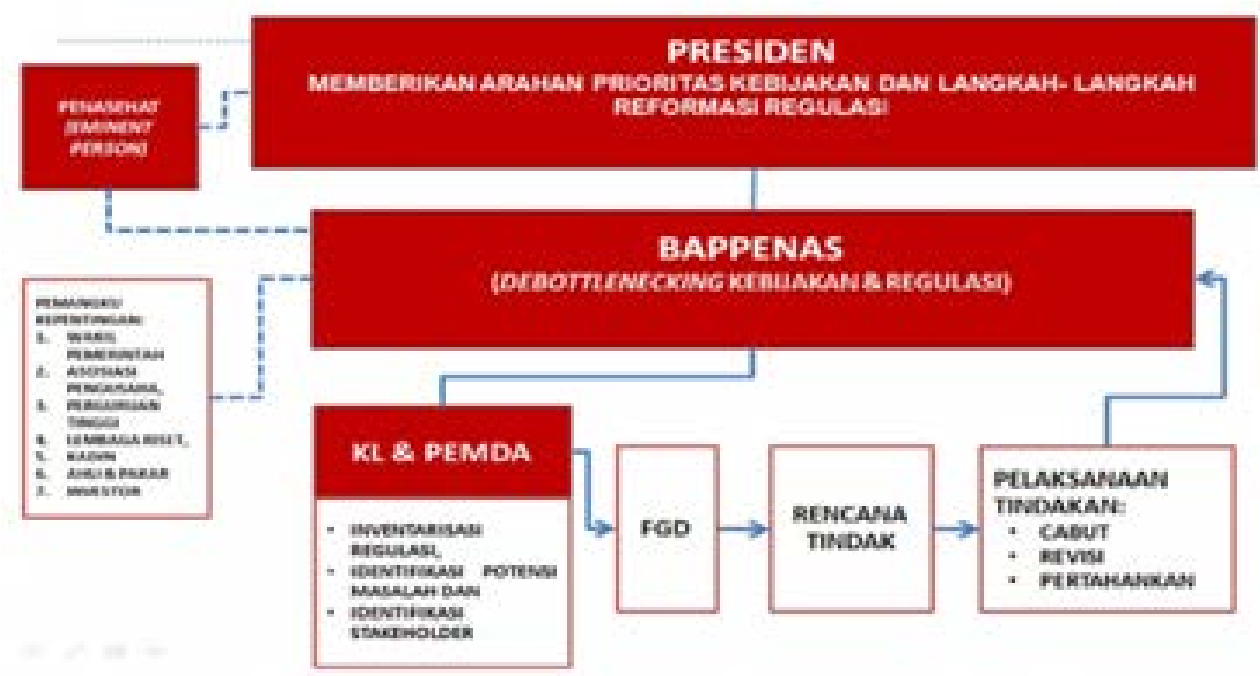

Pada akhir tahun 2016, berdasarkan hasil simplifikasi regulasi yang dilaksanakan oleh 20 $\mathrm{K} / \mathrm{L}$ yang menjadi target pelaksanaan simplifikasi regulasi, didapatkan data sebagai berikut: ${ }^{27}$

1. Dari hasil inventarisasi regulasi, berhasil terhimpun total regulasi yang dimiliki $20 \mathrm{~K} / \mathrm{L}$ tersebut yaitu sebanyak 9106 regulasi.

2. Dari total 9106 regulasi, hanya 1077 regulasi (12\%) yang teridentifikasi memiliki keterkaitan dengan bidang perizinan dan investasi.

3. Dari 1077 regulasi yang terkait dengan perizinan dan investasi tersebut, pada akhirnya dicabut 53 regulasi yang meliputi Peraturan Menteri/Kepala BKPM, BPOM, Kelautan dan Perikanan, Keuangan, Komunikasi dan Informatika, Lingkungan Hidup dan Kehutanan, Ketenagakerjaan, Pariwisata, PUPR, dan Perdagangan.

Berdasarkan data tersebut, menunjukan bahwa langkah simplifikasi regulasi di Indonesia sudah mulai digulirkan terutama di internal pemerintah. Namun dari jumlah regulasi yang pada 
akhirnya diputuskan untuk dicabut, nampaknya pemerintah masih harus bekerja lebih keras lagi dengan menggunakan strategi yang tepat agar target pemotongan $50 \%$ dari total 42 ribu regulasi dapat terwujud.

\subsubsection{Hambatan dan Solusi Pelaksanaan Simplifikasi Regulasi a. Hambatan Pelaksanaan Simplifikasi Regulasi}

Dari hasil pemantauan yang dilaksanakan oleh Tim Stranas Reformasi Regulasi Bappenas terkait dengan pelaksanaan simplifikasi regulasi di tahun 2016, setidaknya ada beberapa hal yang dapat dikategorikan sebagai penghambat pelaksanaan simplifikasi regulasi. Hambatan tersebut dapat berasal dari internal pelaksana simplifikasi regulasi (K/L terkait), maupun dari permasalahan teknis seperti yang terkait dengan teknologi pengelola database regulasi. Adapun beberapa hambatan yang berhasil diinventarisasi adalah sebagai berikut:

- Pembagian peran pelaksana simplifikasi regulasi di internal pemerintah terutama di K/L kunci belum jelas. Setidaknya ada lima K/L inti pelaksana simplifikasi regulasi yaitu Bappenas, Kementerian Koordinator Bidang Perekonomian, Kementerian Dalam Negeri, Kementerian Hukum dan HAM (terutama dengan BPHN dan Dirjen Peraturan Perundang-undangan), dan Kantor Staf Presiden. Pada akhir tahun 2016, masing-masing $\mathrm{K} / \mathrm{L}$ tersebut mengeluarkan data terkait pelaksanaan simplifikasi regulasi. Hal ini menjadi sangat rentan karena dikhawatirkan akan terdapat tumpang tindih database regulasi yang telah disimplifikasi maupun regulasi yang direvisi setelah dilakukan evaluasi oleh $\mathrm{K} / \mathrm{L}$.

- Pelaksanaan simplifikasi regulasi kurang maksimal. Jumlah regulasi yang pada akhirnya diputuskan untuk dicabut setelah melalui proses evaluasi masih jauh dari target. Penyebab utama minimnya pencabutan regulasi tersebut diantaranya adalah evaluasi regulasi masih bersifat sektoral dimana masing-masing $\mathrm{K} / \mathrm{L}$ diminta untuk mengidentifikasi serta mengevaluasi regulasi yang berada di dalam wilayah kewenangannya sehingga masih bersifat bias dan cenderung mengarah ke ego sektoral. Selain itu, belum adanya tools yang disepakati oleh seluruh $\mathrm{K} / \mathrm{L}$ untuk mengevaluasi regulasi yang telah diinventarisasi juga menjadi penyebab kurang maksimalnya pelaksanaan simplifikasi regulasi meskipun tema yang dipilih dirasa sudah kondusif.

- Database regulasi yang belum terintegrasi secara nasional. Meskipun pasca diterbitkannya Peraturan Presiden Nomor 33 Tahun 2012 tentang Jaringan Dokumentasi dan Informasi Hukum Nasional, ${ }^{28}$ pada kenyataannya database terkait regulasi yang dimiliki oleh masing-masing $\mathrm{K} / \mathrm{L}$ belum terintegrasi dengan baik dan juga terkadang data yang dimiliki oleh JDIHN masih kurang lengkap dan kurang update seperti misalkan pada data Peraturan Daerah dimana data yang dimiliki oleh Kementerian Dalam Negeri lebih lengkap dibandingkan yang dimiliki oleh Badan Pembinaan Hukum Nasional (BPHN) selaku pelaksana JDIHN. Hal ini menjadi kendala tersendiri mengingat hasil dari simplifikasi perlu disampaikan kepada seluruh masyarakat terutama stakeholder terkait baik di internal pemerintah maupun di eksternal pemerintah seperti para pengusaha, akademisi, dunia internasional, dan lain-lain.

\section{b. Usulan Solusi Pelaksanaan Simplifikasi Regulasi ke Depan}

Dari hasil identifikasi yang menjadi penghambat dalam pelaksanaan simplifikasi regulasi tersebut, Bappenas berinisiatif untuk melaksanakan Rapat Koordinasi Pelaksanaan Reformasi Regulasi dengan turut mengundang kelima K/L kunci sebagaimana disebut di atas. Beberapa usulan solusi untuk menjawab hambatan pelaksanaan simplifikasi regulasi ke depannya diantaranya yaitu sebagai berikut:

- Secara ideal, untuk melaksanakan reformasi regulasi di suatu negara dibutuhkan sebuah Independent Review Body yang berbeda dari badan atau lembaga Negara yang sudah ada sebelumnya. Sebagai contoh Korea Selatan, pada saat melaksanakan Reformasi Regulasi Tahap I: Deregulasi Masif dari 1998 - 2002 berdasarkan the Basic 
Act on Administrative Regulation, presiden membentuk Presidential Regulatory Reform Committee (RRC). Untuk selanjutnya RRC mengambil peran di dalam perumusan kebijakan dan mempunyai kewenangan untuk menginisiasi perubahan regulasi sejak 1998. ${ }^{29}$ Namun, untuk membentuk sebuah badan baru yang memiliki fungsi sebagaimana yang ada di Korea Selatan akan membutuhkan waktu yang panjang sedangkan pelaksanaan reformasi regulasi di Indonesia sudah sangat mendesak. Upaya awal yang dapat dilakukan adalah dengan melakukan pembagian/pemetaan peran dari K/L kunci sebagaimana tergambar dalam Tabel 3 berikut. ${ }^{30}$ Dari pemetaan peran tersebut diharapkan kegiatan simplifikasi regulasi dapat segera terselenggara dengan hasil terukur.

Tabel 3. Pemetaan Peran K/L Pelaksana Reformasi Regulasi

\begin{tabular}{|c|c|c|c|c|}
\hline No & $\begin{array}{l}\text { Kementerian/ } \\
\text { Lembaga }\end{array}$ & Upaya terkait $\mathbf{R R}$ & Substansi & Keterangan \\
\hline 1 & $\begin{array}{l}\text { Kementerian } \\
\text { Koordinator Bidang } \\
\text { Perekonomian }\end{array}$ & $\begin{array}{l}\text { Paket Kebijakan } \\
\text { Ekonomi - } \\
\text { Deregulasi }\end{array}$ & Simplifikasi Regulasi & \\
\hline 2 & Bappenas & Stranas RR & $\begin{array}{l}\text { Simplifikasi Regulasi, } \\
\text { Kerangka Regulasi, } \\
\text { Rekonseptualisasi, } \\
\text { Restrukturisasi, Penguatan } \\
\text { SDM }\end{array}$ & $\begin{array}{l}\text { Kerangka regulasi } \\
\text { menjadi masukan } \\
\text { bagi penyusunan } \\
\text { Program Legisasi } \\
\text { (Proleg) UU, PP, } \\
\text { Perpres }\end{array}$ \\
\hline 3 & \multicolumn{4}{|c|}{ Kementerian Hukum dan HAM } \\
\hline & a. Ditjen PP & $\begin{array}{l}\text { Perancangan, } \\
\text { harmonisasi, } \\
\text { Publikasi, Database }\end{array}$ & $\begin{array}{l}\text { Perancangan, harmonisasi, } \\
\text { Publikasi, litigasi, fasilitasi, } \\
\text { Database }\end{array}$ & \\
\hline & b. BPHN & $\begin{array}{l}\text { - Perencanaan } \\
\text { pembentukan } \\
\text { regulasi } \\
\text { - Evaluasi } \\
\text { - Database }\end{array}$ & $\begin{array}{l}\text { JDIH } \\
\text { Naskah Akademik } \\
\text { Proleg UU, PP, Perpres }\end{array}$ & $\begin{array}{l}\text { Proleg UU, PP, } \\
\text { Perpres } \\
\text { disesuaikan } \\
\text { dengan prioritas } \\
\text { presiden }\end{array}$ \\
\hline 4 & $\begin{array}{l}\text { Kementerian Dalam } \\
\text { Negeri }\end{array}$ & $\begin{array}{l}\text { Pembatalan Produk } \\
\text { Hukum Daerah }\end{array}$ & Simplifikasi Perda \& Perkada & \\
\hline 5 & $\begin{array}{l}\text { Kantor Staf } \\
\text { Presiden }\end{array}$ & $\begin{array}{l}\text { Paket Reformasi } \\
\text { Hukum Tahap II - } \\
\text { Penataan Regulasi }\end{array}$ & $\begin{array}{l}\text { Akan dibentuk Tim khusus } \\
\text { yang menganalisis dan } \\
\text { menata aturan-aturan yang } \\
\text { tumpang-tindih termasuk } \\
\text { aturan yang perlu dihapus }\end{array}$ & \\
\hline
\end{tabular}

- Dalam hal jumlah regulasi yang pada akhirnya dicabut di tahun 2016 dirasa kurang maksimal, Bappenas mengusulkan beberapa solusi diantaranya sebagai berikut: ${ }^{31}$

1. Pemilihan tema besar regulasi yang akan dilakukan simplifikasi/pemangkasan. Tema besar ini harus selaras dengan prioritas presiden. Sebagai alternatif lain, jenis regulasi yang akan disimplifikasi dapat didasarkan pada jenis regulasi yang

\footnotetext{
29. Jong Seok Kim, 2005, Removing Administrative Barriers to Investment: Korean Regulatory Reform Experience: Menghilangkan Hambatan Administatif untuk Investasi: Pengalaman Reformasi Regulasi di Korea (terjemahan), slide: 7, dapat diakses melalui website www.regulatoryreform. com

30. Sadiawati, Diani, 2017, Sinergi Penataan Regulasi, disampaikan dalam Rapat Koordinasi Pelaksanaan Reformasi Regulasi di bappenas, 30 Januari 2017.

31. Ibid
} 
memiliki jumlah paling banyak berdasarkan hasil inventarisasi K/L.

2. Berkaca pada hasil pelaksanaan simplifikasi regulasi tahun 2016 , pada tahun 2017, proses pelaksanaan simplifikasi/pemangkasan regulasi dilaksanakan dalam dua skema yaitu skema self assessment dan peer assessment. Dalam skema self assessment, $\mathrm{K} / \mathrm{L}$ pelaksana akan melakukan simplifikasi/pemangkasan regulasi yang berada dalam lingkup kewenangan masing-masing seperti yang dilakukan pada tahun 2016. Sedangkan usulan baru yaitu dalam skema peer assessment, setiap Kementerian/Lembaga akan 'dinilai' oleh K/L dan stakeholder lainnya terkait upaya simplifikasi yang telah mereka lakukan pada tahun 2016. Hasil dari peer assessment nantinya berupa pandangan terkait apakah hasil dari simplifikasi tahun 2016 sudah tepat sasaran, yaitu diperlukan untuk mengatasi permasalahan di lapangan, atau malah upaya yang mereka lakukan tidak tepat sasaran untuk mengakomodasi kebutuhan di lapangan. Stakeholder dalam skema ini meliputi K/L lain, asosiasi profesi, asosiasi pengusaha, dan kelompok masyarakat. Adapun hasil dari kedua skema tersebut nantinya akan dilaporkan ke Bappenas melalui sistem monitoring yang telah terbangun ${ }^{32}$

3. Untuk lebih menguatkan legitimasi pelaksanaan agenda tersebut, diperlukan sebuah mandat formal dari presiden dalam sebuah peraturan perundangundangan.

- Permasalahan tidak terintegrasinya database regulasi yang dimiliki oleh masingmasing K/L selama ini tidak boleh dipandang sebelah mata. Hal tersebut memerlukan suatu koordinasi yang masif, terstruktur, serta dilaksanakan secara bersamaan oleh lima K/L kunci. Selain itu, diperlukan komunikasi yang baik antara Sumber Daya Manusia (SDM) yang berkecimpung di dalam ranah regulasi seperti SDM di Biro Hukum atau unit terkait lainnya, dengan SDM yang memiliki kapasitas di bidang teknologi informasi agar tercipta sebuah sistem yang terintegrasi dengan baik, tidak hanya antara K/L kunci di pusat, akan tetapi juga dengan seluruh pemerintah daerah di Indonesia. Saat ini Bappenas sedang menyusun "Modul Pelatihan Reformasi Regulasi" yang di dalamnya juga memuat tentang pemahaman terkait simplifikasi regulasi yang nantinya akan disosialisasikan kepada SDM pemerintah yang tupoksinya terkait dengan regulasi baik di pusat maupun di daerah. Diharapkan melalui pelatihan tersebut akan terwujud sinergi antara SDM di bidang regulasi dengan SDM di bidang teknologi informasi untuk dapat menciptakan sebuah sistem database regulasi yang menyeluruh, terintegrasi antara pusat dan daerah serta akuntabel.

\section{Penutup}

\subsection{Kesimpulan}

Reformasi Regulasi di Indonesia sangat krusial untuk segera dilaksanakan dalam rangka konsolidasi penyusunan perturan perundang-undangan yang lebih demokratis, meningkatkan pertumbuhan ekonomi, dan juga untuk mewujudkan tujuan-tujuan kesejahteraan bagi masyarakat Indonesia, Dalam hal ini, simplifikasi regulasi menjadi langkah awal yang sangat menentukan dalam agenda reformasi regulasi di Indonesia.

Worldwide Governance Indicators (WGI) pada tahun 2015 menunjukkan bahwa kualitas regulasi di Indonesia masih rendah dalam kaitannya dengan dukungan terhadap kemudahan berusaha EoDB (ease of doing business). Selain itu, berdasarkan Global Competitiveness Report (GCR) 2016-17, nilai dan peringkat Indonesia untuk indikator Burden of Government juga masih sangat rendah yaitu dengan nilai atau skor 3.9 dan berada di peringkat ke-37 dari 138 negara. $\mathrm{Hal}$ ini sangat berpengaruh terhadap daya saing Indonesia dengan negara lain sehingga kurang menarik investor untuk berinvestasi di Indonesia.

Arahan Presiden Joko Widodo untuk dilakukan pemangkasan regulasi sebanyak 50\% dari total 42 ribu regulasi merupakan langkah awal yang baik dan menunjukkan komitmen pemimpin negara untuk melaksanakan reformasi regulasi. Hal ini sejalan dengan negara-negara lain yang telah sukses melaksanakan reformasi regulasi seperti Korea Selatan dengan kebijakan Guillotine Approach.

32. Dalam rangka pemantauan pelaksanaan simplifikasi regulasi, Kementerian/Lembaga menyampaikan perkembangan pelaksanaannya melalui sistem pemantauan online melalui laman pelaporan http://10.0.3.3/monitoring dengan dukungan dari Kantor Staf Presiden. Pelaporan dilaksanakan sebanyak 3 (tiga) kali, yakni pada Bulan Juni (B06), September (B09), dan Desember (B12). 
Dalam melaksanakan agenda simplifikasi regulasi pastinya akan ditemukan hambatanhambatan teknis seperti tidak jelasnya pembagian peran antar K/L kunci, tema simplifikasi regulasi yang tidak tepat sasaran, dan juga sistem database regulasi yang tidak terintegrasi di antara K/L kunci dan daerah. Bappenas dalam hal ini berupaya untuk mengkoordinasikan pertemuan dengan $\mathrm{K} / \mathrm{L}$ kunci pelaksana simplifikasi regulasi dan mencoba mengajukan usulan perbaikan pelaksanaan simplifikasi regulasi agar ke depannya dapat lebih maksimal dan tepat sasaran.

\subsection{Rekomendasi Kebijakan}

Agar pelaksanaan simplifikasi regulasi berjalan dengan maksimal dan sesuai dengan target yang diharapkan, maka beberapa langkah kebijakan harus segera dilaksanakan, antara lain sebagai berikut:

1. Untuk lebih memperkuat legitimasi pelaksanaan simplifikasi regulasi di Indonesia, presiden dapat mengeluarkan peraturan perundang-undangan sebagai landasan hokum pelaksanaan. Hal ini juga sebagai bentuk komitmen politik presiden untuk mendukung agenda reformasi regulasi di Indonesia.

2. Agar koordinasi antar K/L kunci dan stakeholder lain yang terkait dengan pelaksanaan simplifikasi regulasi lebih ditingkatkan, sehingga pemetaan peran perlu segera ditentukan agar tidak terjadi tumpang tindih tupoksi dalam rangka menjalankan langkah simplifikasi regulasi.

3. Penguatan peran Biro Hukum dan juga unit lain yang terkait dengan regulasi di masingmasing $\mathrm{K} / \mathrm{L}$ perlu segera dilaksanakan salah satunya dengan peningkatan kapasitas

\section{Daftar Pustaka} SDM melalui pelatihan-pelatihan untuk pelaksanaan agenda reformasi regulasi.

\section{Buku}


Direktorat Analisa Peraturan Perundang-undangan-Bappenas, Pemetaan Hasil Identifikasi terhadap Undang-Undang Sektor yang Berpotensi Bermasalah, disampaikan pada Workshop Koordinasi Strategi Analisa Peraturan Perundang-undangan, Jakarta, 5 Desember 2012.

Kementerian Perencanaan Pembangunan Nasional/Bappenas, 2011, Buku Konsep Pedoman Reformasi Regulasi, Direktorat Analisa Peraturan Perundang-undangan, Kedeputian Bidang Politik, Hukum, Pertahanan dan Keamanan - Bappenas, Juni 2011.

Kementerian Perencanaan Pembangunan Nasional/Bappenas, 2015, Strategi Nasional Reformasi Regulasi: Mewujudkan Regulasi yang Sederhana dan Tertib. Kementerian PPN / Bappenas, Jakarta, Indonesia.

Kementerian PPN/Bappenas, Sekretariat Stranas Reformasi Regulasi, 2017, Laporan Pelaksanaan Simplifikasi/Pemangkasan Regulasi Tahun 2016, Kementerian PPN/Bappenas, Jakarta.

Prof. Dr. Ida Bagus Rahmadi Supancana, 2017, Sebuah Gagasan tentang Grand Design Reformasi Regulasi Indonesia, Penerbit Universitas Katolik Indonesia Atma Jaya, Jakarta, Indonesia.

The Organisation for Economic Co-operation and Development (OECD), 2012, Kajian OECD mengenai Reformasi Regulasi Indonesia: Memperkuat Koordinasi dan Menguatkan Pasar, September 2012, Jakarta, Indonesia.

\section{Peraturan Perundang-undangan}

UUD NRI 1945, diakses melalui website: https://portal.mahkamahkonstitusi.go.id/eLaw/ mg58ufsc89hrsg/UUD_1945_Perubahan.pdf

Peraturan Presiden Nomor 33 Tahun 2012 tentang Jaringan Dokumentasi dan Informasi Hukum Nasional dapat diakses melalui website www.setneg.go.id/index.php?option=com perundangan $\& i d=3623 \&$ task=detail $\&$ catid $=6 \&$ ltemid $=42 \&$ tahun $=2012$

Instruksi Presiden Nomor 4 Tahun 2015 tentang Penyelenggaraan Pelayanan Terpadu Satu Pintu Pusat di Badan Koordinasi Penanaman Modal, dapat diakses melalui website http:// www.kemendagri.go.id/media/documents/2015/04/22/i/n/inpres_nomor_4_tahun_2015. pdf

\section{Internet}

Byung KiHa(1999), The Economic Effects of Korea's Regulatory Reform (in Korean), KIET, dikutip dan diterjemahkan dari http://regulatoryreform.com/wp-content/uploads/2014/11/ removeadminbarriers.pdf

http://info.worldbank.org/governance/wgi/index.aspx\#reports

Jong Seok Kim, 2005, Removing Administrative Barriers to Investment: Korean Regulatory Reform Experience: Menghilangkan Hambatan Administatif untuk Investasi: Pengalaman Reformasi Regulasi di Korea (terjemahan), slide: 7, dapat diakses melalui website www. regulatoryreform.com

OECD, 2004, Implementing Administrative Simplification in OECD Countries: Experiences and Challenges, terjemahan, diakses melalui website http://www.oecd.org/mena/ governance/37026688.pdf.

Qodar, Nafiysul, 2016, Jokowi: Kita Negara Hukum, Bukan Negara Undang-Undang, diakses melalui website: http://news.liputan6.com/read/2623831/jokowi-kita-negara-hukumbukan-negara-undang-undang

Rahadian, Lalu, 2015, Pemerintah Siap Pangkas Beleid Penghambat Pembangunan, Jakarta. Diakses melalui website http://www.cnnindonesia.com/ nasional/20151216121935-20-98578/pemerintah-siap-pangkas-beleid-penghambatpembangunan/

Schwab, Klaus, 2015, World Economic Forum, Insight Report, The Global Competitiveness Report 2015-2016, dapat diakses melalui website: http://www3.weforum.org/docs/ gcr/2015-2016/Global_Competitiveness_Report_2015-2016.pdf

Schwab, Klaus, 2016, World Economic Forum, Insight Report, The Global Competitiveness Report 2016-2017, dapat diakses melalui website: http://www3.weforum.org/docs/ GCR2016-2017/05FullReport/TheGlobalCompetitivenessReport2016-2017_FINAL.pdf

\section{Lain-lain}

Djalil, Sofyan, 2015, disampaikan dalam acara Peluncuran Strategi Nasional Reformasi Regulasi: Mewujudkan Regulasi Yang Sederhana dan Tertib, Jakarta, 6 Oktober 2015 di Gedung Bappenas.

Sadiawati, Diani, 2017, Mewujudkan Agenda Reformasi Regulasi di Indonesia, disampaikan pada acara Launching Buku "Sebuah Gagasan tentang Grand Design Reformasi Regulasi Indonesia” oleh Prof. I.B.R. Supancana pada tanggal 27 Januari 2017 di Hotel Le Meridien, Jakarta.

Sadiawati, Diani, 2017, Sinergi Penataan Regulasi, disampaikan dalam Rapat Koordinasi Pelaksanaan Reformasi Regulasi di Bappenas, 30 Januari 2017. 